\title{
DEEPENING NEOLIBERALISM VIA AUSTERITY AND 'REFORM': THE CASE OF IRELAND
}

Alistair Fraser

Department of Geography, National University of Ireland Maynooth, Co. Kildare, Ireland.

\section{Enda Murphy}

School of Geography, Planning and Environmental Policy, University College Dublin, Dublin, Ireland.

\section{Sinéad Kelly}

Department of Geography, National University of Ireland Maynooth, Co. Kildare, Ireland.

\section{Abstract}

The current economic crisis - the 'great recession' - raises numerous questions about neoliberal ideas and practice, not the least of which is whether (and if so, how) neoliberalism can survive it. Our paper takes on these issues using the case of Ireland. This is the first proper neoliberal crisis in Ireland. From the early 1990 s to 2008 , Ireland was held up by many neoliberal champions as a place that gained from deregulation, openness to inward investment, and low corporation tax rates. But the build-up of contradictions in Ireland exploded rapidly in 2008, when its property bubble burst and private banks and government finances collapsed. Rather than examining what caused Ireland's crisis, we look at what has happened between 2008 and 2013. We focus on structural adjustments regarding the property, finance, and labour markets and then on the government's austerity programme as a whole. In addition to demonstrating how these adjustments have been an attack on workers and ordinary citizens, we identify some particularly striking elements, which we use to argue that a new phase of disturbance and restructuring is deepening and extending neoliberalism's influence in Ireland.

Key Words: neoliberalism, Ireland, structural adjustment, austerity, Europe.

Profundizando el Neoliberalismo por la vía de la austeridad y la reforma: el caso de Irlanda

\section{Resumen}

La crisis económica actual -la gran recensiónplantea varias preguntas acerca de las ideas y prácticas neoliberales, incluyendo si y de que manera, puede el Neoliberalismo sobrevivir la presente crisis. Nuestro 
artículo aborda estas preguntas utilizando el caso de Irlanda. La crisis actual es la primera crisis Neoliberal que ocurre en Irlanda. Desde principios de los 90s hasta el 2008, varios defensores del neoliberalismo sostenían que Irlanda era un lugar que se beneficio de la desregulación, la apertura a la inversión y los bajos impuestos a las corporaciones. Sin embargo, en el 2008, la acumulación de contradicciones llevo a que explotara la burbuja de la propiedad, seguida del colapso de los bancos privados y las finanzas gubernamentales. En este articulo, vez de examinar las causas de la crisis Irlandesa, nos enfocamos en los eventos que ocurrieron entre 2008 y 2013. Específicamente en el ajuste estructural concerniente a la propiedad, finanza, mercados laborales y luego en el programa gubernamental de austeridad en su conjunto. Además de demostrar como estos ajustes constituyen un ataque a los trabajadores y ciudadanos, identificamos algunos elementos llamativos para proponer que una nueva fase de disturbio y restructuración esta profundizando y extendiendo la influencia del Neoliberalismo en Irlanda.

Palabras clave: neoliberalismo, Irlanda, ajuste estructural, austeridad, Europa.

\section{Introduction}

We are living through the world's first full-scale neoliberal capitalist crisis - an existential crisis that calls into question the future of these peculiar and nefarious ideas and practices. The crisis has demanded attention from critical scholars because of the dominance of neoliberal ideas about how the capitalist economy and polity should be organized (e.g. see Harvey, 2003, 2005; Klein, 2007; Peet, 2009). Processes of neoliberalization underway in the last forty years - based on ideas and practices revolving around privatization of state-owned assets, deregulation of economic sectors, and openness to investment flows - have generated a most extraordinary and unjust redistribution of wealth and power from working to ruling classes, particularly the owners and controllers of transnational industrial and financial corporations. And neoliberal adherents and champions have successfully managed to colonize the world of ideas; that is, dominating debates about the past, present, and future, and normalizing its key tenets of 'freedom' (to accumulate, primarily) and 'rights' (to, as far as possible, be left alone by the state, albeit with important exceptions, not least in times of crisis) (Frank, 2000). They have restored class power to capitalists (Harvey, 2003) and fundamentally shaped the terms of debates about the way society, the state, and the market should interact.

In this paper, we question how adherents and practitioners of neoliberal ideas seek to deal with the contemporary crisis, the 'great recession' which has been unfolding since 2008. Although in particular contexts it appears to be merely a crisis of state revenues or of one sector of the capitalist economy, we view the current crisis as a first-order crisis with origins in capitalism's deepest internal relations. At issue is demand and how it can be generated. If not by credit, as has been the approach in recent years, then via what strategies is the neoliberal capitalism show to be kept on the road? Whereas Keynesian economic thinking calls for interventions to get production going in times of crisis, neoliberal ideology, as we are seeing currently, calls for greater 'freedom' for entrepreneurs, debt-repayment, and deeper austerity. But the problem of demand persists because, 'Wage repression produces a deficit of effective demand that is covered by increasing indebtedness that ultimately leads into a financial crisis which is resolved by state interventions which translates into a fiscal crisis of the state that can best be resolved, according to conventional economic wisdom, by further reductions in the social wage' (Harvey, 2010). Crucially, the absence of demand presents a serious problem for cash-rich investors: lacking a clear sense of when demand of sufficient quantity will emerge, they horde rather than spend and employ, thereby exacerbating the problem (Harvey, 2005, 2010). The most fundamental issue today is therefore material inequality and the extraordinary extent to which neoliberalism has enabled employers and the owners of capital to acquire an enormous and growing share of the surplus. For the global capitalist economy to find a way out of the crisis, spending in the order of hundreds or indeed thousands of billions of dollars is needed. ${ }^{1}$ But just such a scale of investment is hard

1 Indeed, Harvey (2010) argues that US\$1.7 trillion of new profitable investment opportunities per year need to be generated by the global economy in order to absorb 
to create without the straightforward (but for neoliberal practitioners, seemingly unthinkable) solution of redistributing wealth. Whether (and why, or why not) attempts to resolve the crisis move in this sort of direction is one question for the sort of research critical scholars must undertake.

However, an important complicating factor here is that neoliberalism has developed alongside a process of globalization, which gives a certain shape to the capitalist economy that alters the sorts of relationships that might develop between central banks and the decisions of investors, not least about when and where to invest capital. For example, even if the European Central Bank lowers interest rates in the crisis-ridden Euro-zone or pumps billions of Euros into its banking system to encourage the sort of investment capitalism needs, there is little compulsion for European banks to lend that money locally, hence no guarantee that European workers will, as a result, find employment. Nor is it certain that such liquidity will be invested productively at all; indeed, the restructuring of 'advanced' economies away from production towards increasingly speculative activities virtually guarantees that it will not. Globalization also makes it hard for solutions to the crisis to be found, not least because of the growing reliance on China. Just as politicians and finance ministers in Europe might look to China to generate demand, so they are confronted with the peculiarities of capitalism's uneven development there. As Hung (2009), notes, the Chinese state faces an enormous challenge in overcoming the political and economic power of coastal elites if it is to deliver on the demand for a more balanced form of development between coastal and interior regions. He argues that the challenge is to 'stimulate the growth of domestic demand by increasing the working classes' disposable income [but such] a redirection of priorities has to involve moving resources and policy preferences away from the coastal cities to the rural hinterland, where protracted social marginalization and underconsumption have left ample room for improvement' (p.24). Such nuanced dynamics of globalized capitalism - how the tensions internal to one economy

existing surplus capital and return the capitalist system to a compound growth rate of $3 \%$. reach into and complicate the tensions in distant others - make it difficult to imagine how capitalism can put to work the millions of unemployed workers in the so-called 'advanced economies', never mind the billions enduring a 'wageless life' (Denning, 2010) in the 'global south'. Capitalism seems to need something other than neoliberal ideas and practices but there remain few signs that such a shift is underway.

In this general context, therefore, we argue it is important that scholars analyze not just the many causes of the current situation, but also how decisionmakers in government or in institutions of the national (and supra-national) state try to deal with it. Are decision-makers rolling back or extending and deepening neoliberalism? What 'innovations' are conjured up in the hope of restoring growth? In what ways does the more global context shape the strategies of ruling classes in particular places? In other words, just what are 'the imperatives, ability and the willingness of different governments to use their powers (either individually or collectively) to confront the crisis' (Harvey, 2010)? Our paper considers these sorts of questions using the case of Ireland, a capitalist economy in which Gross Domestic Product slumped by $11.1 \%$ between 2008 and 2011 and unemployment soared from $4.8 \%$ in early 2008 to $14.2 \%$ in 2013 . We ask how its political and ruling class - that is, its leading politicians, governing political parties, as well as capitalists in the banking, finance, property and other sectors - have sought to find a way to handle, resolve, or indeed displace the numerous problems that have emerged from the crisis in Ireland.

Ireland is a particularly interesting case study for two reasons. One is that it was so widely acclaimed as a shining example of what could be achieved if a state enacted deregulation, privatization, and left itself open to global capital flows, even if its emergence as a beacon of neoliberal practice was in some respects accidental, 'the product of a complex set of unfolding, interconnected, often serendipitous, processes held together by a strategy of seeking to attract and service FDI' (Kitchin et al., 2012a: 1306). Its rapid descent therefore calls into question the efficacy of these approaches to capitalist development. 
The second reason is about the peculiar way Irish workers and citizens have negotiated the crisis. As we will discuss, Ireland entered into an $€ 85$ bn bailout agreement with the European Commission of the European Union, the European Central Bank, and the International Monetary Fund (widely referred to in Ireland as the EU-ECB-IMF 'troika') in late 2010. Under the terms of this agreement, the Irish government has pursued a wide range of 'structural reforms'. Of course, there have been other such bailouts in Europe - in Greece, Portugal, Spain, and most recently in Cyprus - but Ireland sticks out because its bailout and the associated austerity has not been met with significant sustained resistance from trade unions and civil society. There have been protest marches, demonstrations, and campaigns against particular aspects of government policy, but even amidst deep cutbacks in state spending and rising unemployment, only 3,695 days were lost to industrial disputes in 2011, the lowest number since records began in 1985. And in 2011, the Irish electorate overwhelmingly voted for two parties that promised to implement austerity rather than oppose it, as many argued was possible and necessary. It is almost as if the general populace has given their passive consent to the austerity. In this sense, Ireland appears to be somewhat of an oddity, a place deserving attention from critical scholars interested in the machinations of corporate and political power and the embodiment of class relations within contemporary austerity programmes.

We organize the rest of the paper as follows. We begin by briefly introducing Ireland's crisis, before examining three elements of the Irish state's adjustment and austerity programme. We specifically focus on adjustments in the areas of property and finance, the labour market, and state spending. In a discussion and conclusion, we reflect upon the way that neoliberal ideas and practice have been deepened and extended via new processes and patterns of disturbance.

\section{Ireland's Crisis}

Much of what we need to discuss about the causes of Ireland's crisis is well-documented elsewhere (e.g. see Allen, 2007; Finn, 2011; Kitchin et al., 2012a;
O’Toole, 2009; Ross, 2009), hence the brevity of the following discussion. Ireland was one of the poorest states in Europe in the 1980s but rose to become one of the wealthiest (at least, in terms of GDP per capita) by the mid-2000s. It achieved this transformation via European supports, inward investment propped up by a low rate of corporation tax, and labour market reforms (including a pact between private capital, the state, and trade unions which was designed to secure peaceful and stable conditions in the public sector that would form the basis for accumulation to occur in the private sector). In the last few years of this growth spurt, however, Ireland's property market entered a highly contagious, high-risk bubble phase. Property values, property-related lending, and employment in the construction sector all dramatically increased. For example, the total value of mortgage debt 'increased, from $€ 47.2$ billion in 2002 to over $€ 139.8$ billion at the end of 2007'; and house prices followed a similar trajectory, reaching a peak of $€ 322,634$ for the average new home (a 382\% increase since 1991) (Kitchin et al., 2012a: 1308).

All of this fell apart from 2007 onwards. The banks were among the first casualties, with the state extending to them an unlimited guarantee of their liabilities in late 2008, thereby socializing their losses - a move widely hailed as the worst decision ever made by an Irish government (e.g. see Münchau, 2010). Numerous firms in the construction sector began collapsing under the weight of enormous debts to Irish and foreign banks. As the crisis unfolded further, it hit all other sectors of society. Unemployment - which had fallen from about 200,000 in the mid-1990s to a low of 67,000 in 2001 - surged rapidly from 100,000 in 2007 to 300,000 by 2010. The state's finances deteriorated. Although the Fianna Fáil government began an extensive and deep austerity programme, escalating borrowing costs and capital flight forced it to accept an EU-ECB-IMF bailout in late 2010. The sovereign Republic had reached a new nadir. In a general election in 2011, Fianna Fáil was voted out and a new coalition government of Fine Gael and Labour took office. Since 2011, and not surprisingly given that the new regime has continued with the austerity policies, matters have deteriorated further. Even a team of IMF 
specialists expressed alarm at Ireland's situation, noting in a recent review that: 'Involuntary part-time employment increased, and migration patterns reversed, with Irish citizens emigrating in search of jobs. Long-term unemployment has risen sharply, raising the risk of permanent skill losses among jobseekers and hence a decline in potential output in future' (IMF, 2012: 58).

Against this backdrop, numerous analyses of Ireland's situation have emerged in the last few years. By far the largest volume of work on the run-up to the crisis has been conducted by prominent Irish commentators and journalists (e.g. see O’Toole, 2009; Ross, 2009). For its part, the critical academic literature on Ireland's crisis is actually quite thin. Finn (2011) has positioned Ireland's crisis relative to the broader European question, as well as Ireland's geo-historical development since independence. In addition, there is a rich contribution from Kitchin et al. (2012a), which provides an excellent overview of the property bubble's growth and the state's attempt to resolve the property problem via the National Asset Management Agency (NAMA). Finally, Kitchin et al. (2012b) demonstrate some of the complex local specificities emerging from the bubble, particularly in the so-called 'ghost estates' scattered throughout the country. ${ }^{2}$ Our contribution to this literature is to examine what has happened in Ireland since 2008. But rather than only looking at adjustments in the property sector, as per Kitchin et al. (2012a), we also examine adjustments in the labour market and in state spending. Our aim is to identify some of the most striking effects of these adjustments with a view to shedding light on the specific way Ireland's neoliberal crisis is unfolding. We choose this organization because it follows the prioritization of the Irish government.

\section{Reform and adjustment in the finance and property sectors}

Without question, everything about the crisis in Ireland has been shaped by the state's bank guarantee, announced on 30th September 2008 amidst fears that Ireland's so-called 'pillar' banks would collapse under

2 Numerous additional contributions have been posted by academics, many of them geographers, on the Ireland After Nama blog at http://irelandafternama.wordpress.com. the weight of bad loans and falling deposits. In one move, the state assumed responsibility for all debts and deposits held in the six main Irish financial institutions, amounting to $€ 485$ bn or $271 \%$ of GDP (Drudy and Collins, 2011). The state then made further interventions in the banking system and property markets: by February 2009, two of the six financial institutions (Anglo Irish Bank and Irish Nationwide Building Society (INBS)) were fully nationalised; that same year, a total of $€ 11$ bn was injected directly into the three biggest banks, Allied Irish Banks (AIB), Bank of Ireland (BoI) and Anglo. By June 2011, AIB, Irish Life \& Permanent and EBS were effectively nationalized and the state took a larger stake in BoI. Further restructuring has occurred, such as the state's decision in 2011 to subsume EBS within the much larger AIB and, perhaps more notably, the move to form the Irish Bank Resolution Corporation (IBRC) from state-owned Anglo and INBS, the two most reckless lending institutions during the bubble. In short, the banks have been bailed out by the state in what is a massive departure from the neoliberal narrative of minimal state intervention. Indeed by June 2012 they had received $€ 64 \mathrm{bn}$ from the state. With a mortgagedefault crisis still looming large on the horizon, more support will yet be required. The obvious implication of these interventions has been the wholesale transformation of private debt into public debt. The burden of paying for one of the biggest property and banking collapses in the history of capitalism has been thrust onto workers, taxpayers and ordinary citizens. But within the specifics of these adjustments, there are some interesting features that speak to the way Ireland is negotiating the crisis.

In late 2009, for example, the government created the National Asset Management Agency (NAMA), taking into state ownership a huge portion of the banks' impaired loan books, mostly relating to commercial property. It paid €32bn against the banks' valuations of $€ 77 \mathrm{bn}$, but even at this lower valuation point NAMA looks set to struggle to recover the state's spending over its ten-year lifespan (see Kitchin et al., 2012a), not least because property prices are still falling in Ireland where most of the 'assets' are located. NAMA has pursued some of the debtors, for example by appointing receivers to 93 of its 190 major 
borrowers, and taking possession of $€ 500 \mathrm{~m}$ of assets that had been transferred by debtors to their spouses and other relatives in an attempt to preserve their wealth (Irish Times 2011a). Some of these moves have been quite high profile, such as proceedings against Treasury Holdings and NAMA's support for the nationalized Anglo Irish Bank (IBRC) in a legal battle with failed-capitalist Sean Quinn, Anglo's largest debtor owing $€ 2.88 \mathrm{bn}$. In these cases, therefore, the state's bad bank is actively engaged in reconfiguring power relations in Ireland, although only in cosmetic ways that tinker around the edges of the political economy by shifting assets and wealth between elites.

NAMA's moves in this regard alter Ireland's place in the world (if one sign of Irish capitalism's successful use of neoliberal ideas and practice was the presence of Irish property-owners in London, New York, Berlin, or Budapest, then high profile fire sales of those assets are equally emblematic [Financial Times, 2012]), as do some of the state's other actions in the property sector. In particular, the creation of new property investment opportunities highlight some of the ways in which the state is becoming more entrepreneurial by instituting new arrangements that seek to facilitate foreign finance capital more overtly, or by pursuing a degree of legal and financial engineering aimed at altering the particular way Irish and international finance and property sectors interact. Thus, NAMA has offered 'vendor financing' (€2bn thus far) in the commercial property market to extend loans to prospective buyers for up to $70 \%$ of the market price of office buildings and other commercial assets on its books. As outlined by Frank Daly, Chairman of NAMA, the bad bank's strategy here is intended to 'unlock' (NAMA, 2012: 6) international investor interest in Ireland's commercial property sector. It is also instructive to note that the government's Finance Bill 2013 has devised new policy instruments, most notably Real Estate Investment Trusts (REITs), to entice international investors to acquire unsold commercial and residential assets. The outcome of this move is uncertain, but one possibility is that foreign institutional investors might take a considerable stake in the residential property sector, particularly unsold apartment developments in central Dublin which offer considerable potential for increasing investment returns in the private-rental sector. Traditionally, the residential market in Ireland has been the domain of small-scale property capital with institutional investors and larger funds hitherto steering clear of this riskier property type.

In the banking and finance sector, too, post-crisis adjustments have altered Ireland's position relative to the wider flows of capital. Perhaps the most noteworthy of these has been the withdrawal of foreign banks such as Halifax (Bank of Scotland) and Northern Rock; in addition US corporate giant Liberty Mutual Insurance entered the Irish market by purchasing Quinn Insurance in 2012. These moves alter Ireland's economy in incremental but serious ways. Liberty, for example, will pay dividends to its parent company, which means profits earned in Ireland, a lot of which was held and reinvested domestically, will be repatriated to US shareholders. ${ }^{3}$ Tactics such as these - where US (and other) multi-national corporations buy up distressed assets ${ }^{4}$ in a form of 'vulture capitalism' - are entirely consistent with the tenets of neoliberal structural adjustment programmes devised specifically for the exploitation of national assets by foreign capital in developing countries.

Crucially, however, at the same time as the state has tried to re-engineer the finance and property sectors, some key structural components have been protected and indeed boosted. For example, in February 2013 the coalition government pushed through emergency legislation in a special all-night sitting of the Dáil to liquidate Anglo/IBRC. The government's rationale was to delay the repayment of state-backed promissory notes on the Anglo/IBRC

3 Meanwhile, the departure of Halifax (Bank of Scotland) and Northern Rock will further reduce competition in the banking sector and improve the prospects for Irish stateowned and merged banks.

4 Of note here is the decision by the giant U.S. private-equity and venture capital company, Blackstone, to purchase the Burlington Hotel, one of many 'distressed assets' owned by IBRC (formerly the notorious Anglo Irish Bank). Bought by an Irish property developer in 2007 for $€ 288 \mathrm{~m}$, Blackstone paid just $€ 67 \mathrm{~m}$ (a discount of 77\%) in November 2012 (Irish Times 2012a). Blackstone had also been contracted by IBRC to advise on the divestment of its (formerly Anglo's) remaining Irish and British loans of $€ 30 \mathrm{bn}$. 
debt due in March 2013 and instead to swap them for long-term sovereign bonds. Additionally, as part of the deal, the government directed NAMA to purchase $€ 15 \mathrm{bn}$ of IBRC debt from the Central Bank of Ireland and to transfer IBRC's remaining assets to the NAMA portfolio. While these moves may serve to reduce the state's annual debt repayments in the short term, it has exposed the Exchequer and NAMA (and by extension Irish citizens) to further losses; it remains the case that senior bondholders will be paid in full while NAMA and the Exchequer must cover any further shortfalls arising from the disposal of IBRC assets (IMF, 2013). The key aspect to note here is that when it comes to decision-making about banking debt, the state has been swift to act. Successive governments have introduced urgent measures that effectively solidify bank debt as sovereign debt and deepen the state's commitment to ensuring that workers and citizens bear the burden of such debts. Also notable here is the absence of such swift and urgent government action to deal with mortgage and other forms of personal debt.

In addition, although they made a commitment to ban upwards-only rent reviews, an oddity of Ireland's commercial property sector, the new government has maintained these types of leases. This move follows on from the introduction of capital incentives for investment property in Budget 2012, which means investors buying commercial property before the end of 2013 will not pay tax on capital gains provided the properties are held for at least seven years, a move designed to bolster the commercial property sector. Meanwhile, the government introduced a flat $€ 100$ residential household charge in 2012, followed by a new (IMFbacked and crude) market-valuation-based residential property tax. Under well-publicised threats of significant financial and legal penalties for non-payment, most households are likely to face new property-tax bills of $€ 202$ in 2013 and $€ 405$ in 2014.

Given all of these adjustments, it seems abundantly obvious that the new coalition government has sought to reinforce the power of property investors, thus ensuring that potential returns to (investment) property will be maximized, even in a declining market. Fundamentally, the responses to the property crash in the form of REITs, vendor financing and the capital investment plan are attempts to free-up, increase and enable further investment, as is evident from NAMA's recent (as of early 2013) decision to invest $€ 2 \mathrm{bn}$ in new development and development completion, which contrasts sharply with the substantial level of cuts in state spending in other non-property-related sectors of the economy. Indeed, with each successive state response signalling a deepening prioritisation of - and further support for - property, banking and finance sectors, these types of interventions become normalized. It is hardly surprising, therefore, that NAMA supports at least 100 developers, many of whom are receiving salaries in excess of $€ 100,000$, at the same time as the government aims to pass a Personal Insolvency Bill which will empower banks to scrutinize and veto the spending of homeowners in mortgage arrears. Indeed, the question of mortgage arrears is one of the most fraught and unresolved elements of the Irish crisis. At the end of 2012, almost one-fifth of all residential mortgages were in arrears, with the remaining outstanding balance on those mortgages-in-arrears amounting to over $€ 30 \mathrm{bn}$ (Central Bank of Ireland, 2013). ${ }^{5}$ Just how the banks will handle these debts is unclear, but a vicious pursuit of households in arrears seems likely.

\section{Labour sector adjustments}

In addition to adjustments in the property and finance sectors, Ireland's response to the crisis has been aimed at labour. One major line of attack on labour has specifically targeted public sector workers. The first part of this was a pension levy and pay cut which resulted in a $14 \%$ reduction in take-home pay for all public sector workers (LRC, 2013). In addition, staff numbers were cut by about 15,000 between 2008 and 2010. These attacks were followed in June 2010 by a Public Service Agreement (PSA) between the government and public sector unions. Known locally as the Croke Park Agreement, it entailed a pay freeze between 2010 and 2014. As such, while nominal wages have remained stagnant, real wages have declined at a rate equivalent to the annual rate of

5 These figures include all arrears on principal-dwelling and buy-to-let mortgages at the end of 2012. Arrears of more than 90 days amounted to $13 \%$ of the total number of mortgages (Central Bank of Ireland, 2013). 
inflation. ${ }^{6}$ But the agreement also included numerous other 'reforms'. One was an Employment Control Framework (ECF) for each sector, which placed a moratorium on recruitment and froze promotions, thereby stunting career paths within the sector; by February 2013, the agreement had delivered a reduction of staff numbers by 17,300. Overall, the agreement reduced the government's public sector pay bill by c. $€ 1.5$ bn between 2010 and 2012 .

This attack on public sector workers has continued and deepened. In February 2013 the government reneged on the PSA agreement and announced a revision of its terms in consultation with the major unions, culminating in a new draft agreement dubbed 'Croke Park II'. The new proposals are even more hostile to public sector workers. The draft agreement proposed direct pay reductions of between $5.5 \%$ and $10 \%$ for workers earning over $€ 65,000$; the timeline for the ECF will be extended to 2016; and controversial measures introduced in the first PSA, such as mandatory 'flexible redeployment' of staff 'within and across sectors' of the public service and potentially in an entirely different geographical area, have been deepened and extended through 'workforce planning' and 'Workforce Action Plans' that 'support management in identifying the skills deficits as well as staff surpluses within organisations...' (LRC, 2013: 9). Furthermore, whereas the first PSA gave management greater surveillance powers to monitor workers' activities through the introduction of 'performance verification' aided by sector-wide 'performance management systems' (Department of PER, 2010: 4-5), the new proposed deal will entail new 'performance improvement action plans' for individuals with 'performance issues that need to be addressed over a defined timeframe' (LRC, 2013: 12). If the government's approach to the first PSA involved shaking the confidence of public sector workers by adjusting their expectations regarding pay and conditions, the latter agreement seeks to entrench neoliberal-style work practices and conditions as the new norm in the public sector.

6 The cumulative rate of inflation since 2010 until February 2013 is 4.6\%: 2010 (-0.93); 2011 (2.59); 2012 (1.72); 2013 (1.21). Thus, including the pension levy, pay cuts, and inflation considerations, direct cuts to income since the onset of the crisis are between $24.1 \%$ and $28.6 \%$.
Without any doubt, these agreements are intended to discipline labour, not just in the public sector but in the workforce as a whole. Even though the proportion of workers covered by collective agreements had fallen at an EU-leading rate in Ireland between 2000/01 and 2008/09 (ILO, 2012: 41), the state's public sector workers still demonstrate that not every worker has to labour under insecure, overly-flexible conditions and for low pay. In these ways, the state's response to the crisis has been to attack labour with a view to achieving a greater return of economic output to capital (which has been achieved - see Figure 1).

The aforementioned attacks on public sector workers map neatly onto attacks on labour in the private sector more generally. Most visibly, private sector workers have been hit by redundancies, contributing to a current unemployment rate of $14.2 \%$ as private sector employment numbers have been slashed by $18 \%$ since the second quarter of 2008 (IMF, 2012: 63). Many firms have also used the crisis as a way of increasing the rate of exploitation of workers by reducing staff numbers and/or cutting wage rates irrespective of profitability. Moreover, all workers in Ireland have been struck by new policies that stem directly from the EU-ECB-IMF bailout agreement. For example, one of the 'structural reforms' aimed at 'facilitat[ing] adjustment in the labour market' and 'reduc[ing] the risk of long-term unemployment' (Department of Finance, 2010: 20) extended the 'inability to pay clause,' which encourages employers to renege on wage agreements. ${ }^{7}$

Other labour market changes are intended to reform 'the system of activation policies', for example via: 'the introduction of instruments to better identify job seekers' needs ("profiling")'; 'more effective monitoring of jobseekers' activities with regular evidence-based reports'; and 'the application of sanction mechanisms for beneficiaries not complying with jobsearch conditionality' (p.21). Thus, under the supervision of the Minister for Social Protection,

$7 \quad$ The Inability to Pay Clause enables employers not to pay all or some of the pay increases due in a wage agreement. The clause is part of recent national wage agreements. At present, it cannot be invoked more than once in a five-year period, but the EU-ECB-IMF agreement looks set to change that. 


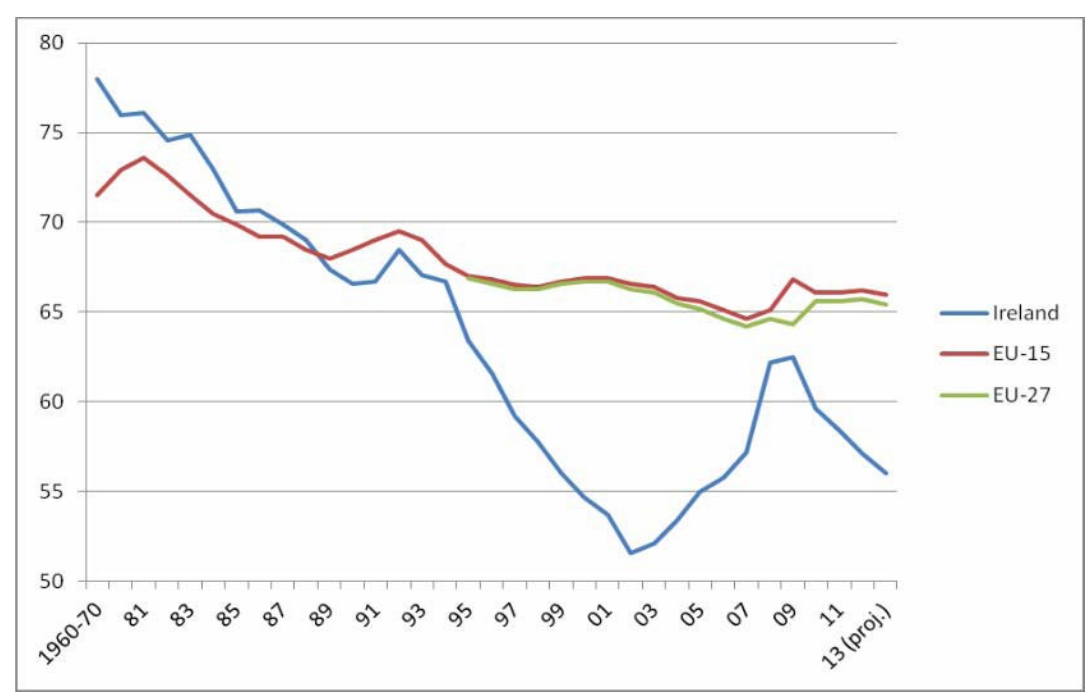

Figure 1: Labour share of economic output (GDP), 1960-2013 Source: Compiled using data from European Commission (2011) Statistical Annex of European Economy, Autumn 2011. Available at: http://ec.europa.eu/economy_finance/ publications/european_economy/2011/pdf/2011-11-10-stat-annex_en.pdf socio-economic realities of unemployment in an effort to re-imagine the relationship between Ireland's industrial reserve army and the state. Rather than an inevitable feature of life in a capitalist society, unemployment is now constructed and managed as an individual and personal failing. Pathways is therefore fundamentally about structurally adjusting the unemployed via micro-scale changes that reorient attitudes towards welfare and exert pressure on those in work to accept poorer working conditions - exactly the sort of change that employers believe will re-position Ireland within the competitiveness league tables. That such changes will have negative consequences for all workers goes without saying; likewise, it is hard not to conclude that this Labour Party TD Joan Burton, the government has moved to 'reform' the state's welfare system. Reminiscent of Workfare programmes in the US (MacLeavy and Peoples, 2009; Peck, 2001), these reforms include a Pathways to Work programme that aims to 'ensure that each person in receipt of job-seeker payment fulfils their personal responsibility to engage fully with the employment and training supports provided by the State, as a pre-condition for receipt of their welfare payments' (Department of Social Protection, 2012: 9). More generally, the plan explicitly aims to re-think the state's relationship with the unemployed. This move reflects general neoliberal thinking in the area of welfare reform, which seeks to 'activate' the unemployed even if, as in Ireland's case, there are few jobs to be had. In the absence of employment opportunities, Ireland's Pathways programme looks to push the unemployed onto a Community Employment system in which they work for 19.5 hours per week in community organizations or groups - with the other hours of the work presumably intended to be dedicated to becoming 'more active in their efforts to find work' (p.10) - in return for which they receive a small extra amount (at least $€ 20$ ) on top of their welfare payment (FÁS, 2012). In so doing, the government aims to reach into the households and communities most affected by the crisis and alter the sort of 'reform' is intended to boost net emigration in Ireland, which has totalled just under 90,000 between 2010 and 2012 (CSO, 2012).

Curiously, however, but certainly not unexpectedly given the dominance of neoliberal thinking in Ireland, another of the state's responses to the crisis has secured taxation relief for elite, 'highly skilled' foreign workers. For example, under the Special Assignee Relief Programme (SARP) introduced in the 2012 budget, an employee can make a claim to have $30 \%$ of their income between $€ 75,000$ and $€ 500,000$ disregarded for income tax purposes. The legislation was partly drafted by Deloitte and KPMG (Irish Times, 2012b), with numerous other interest groups, including the American Chamber of Commerce, offering support. The underlying hypocrisy of allowing high-earning workers to escape taxation whilst low-paid workers and those relying on welfare are attacked is particularly striking, as is the way SARP reflects the Irish state's continued commitment to touting for inward investment using whatever tax tricks it can muster. It is also illuminating because SARP reflects Ireland's effort to position itself as a financial services centre and a new high-technology location focusing on innovation in areas such as bio-technology, social media and cloud computing. That so much of the country's 
misplaced property investment is intended to meet the demands of these sorts of investors - in areas such as Dublin's docklands - highlights the extent to which labour market reforms of this sort are central to the so-called 'recovery' programme.

\section{General austerity}

The third and final element of post-crisis adjustment in Ireland is a general programme of austerity. From a relatively strong position in 2006 and 2007, the Irish government's finances deteriorated rapidly as the crisis unfolded. Exchequer tax revenues all but collapsed from $€ 47 \mathrm{bn}$ in 2007 to just $€ 31$.8bn in 2010, while spending commitments continued, generating large budget deficits. To adhere with the EU's Stability and Growth Pact, which calls for budget deficits of no more than 3\% of GDP, the outgoing FF government began implementing far-reaching fiscal adjustments; the new Fine Gael and Labour coalition government elected in 2011 has continued on the same course, albeit one influenced by the terms of the troika bailout. The adjustment as a whole has entailed efforts to raise funds via asset sales, such as the privatization of forests, but more significantly via wide-ranging spending cuts in social welfare, healthcare, education, and capital investment. The form these cutbacks have taken and their effects on Irish society speak volumes about the way adjustment has occurred. The headline here is that material inequality in Ireland has increased. Government savings have been sought by attacking many of the most vulnerable in society, whilst also extending relative protection to those on higher incomes; that is, as indeed many (no doubt, well-paid) commentators in Ireland point out, austerity has hit high-earners but not nearly as viciously as those on low incomes.

This pernicious orientation to austerity was evident from the outset. For example, in Budget 2010 (announced in late 2009), the FF government announced reductions in social welfare payments of $€ 760 \mathrm{~m}$, including cuts in Child Benefit and Disability Allowance, with the latter rate reduced from $€ 204.30$ per week to $€ 196$, an $€ 8.30$ per week cut, which affected 96,000 people and saved the government
$€ 41 \mathrm{~m}$ a year. In the same budget, however, and at a time when its calamitous position gave it plenty of scope to do so, the government left corporation tax untouched at $12.5 \%$. A year later, Budget 2011 further reduced the social welfare bill, this time by $€ 873 \mathrm{~m}$. There was a reduction of $€ 8$ per week for adults claiming the personal rate of Jobseeker's Allowance and a health and income levy on earnings was replaced by a new Universal Social Charge of 7\%, which was to apply regardless of whether earnings were $€ 20,000$ or $€ 200,000$ (TASC, 2010: 8), thereby hitting those on low incomes in a highly regressive manner.

Following the 2011 election, the FG-Labour government's first budget - Budget 2012, the first supervised by the troika - cemented and further entrenched the process of regressive austerity, not least via an increase in the standard rate of Value-Added Tax (VAT) from $21 \%$ to $23 \%$. The budget also hit poorer families by reducing child benefit payments and tightening entitlements to payments for back-toschool clothing and footwear, cuts which would have even harsher effects on the, 'lowest income household grouping in society [which] is the single parent with children group. This group was targeted with cuts to the one parent family payment, cuts to child benefit for the third and subsequent children and cuts to the back to school clothing and footwear allowance' (TASC, 2011: 2). Yet again, however, the government steered away from hitting those on higher incomes, thereby living up to pre-election promises not to increase income tax. Partly for this reason, the budget was warmly welcomed by influential business elites as 'pro-business pro-growth' (Irish Times, 2011b).

Finally, in Budget 2013 the government pursued an adjustment of $€ 3.5 \mathrm{bn}$ via spending cuts and new taxes. Standout changes included a further $€ 450 \mathrm{~m}$ reduction in the social welfare budget, including a reduced rate of child benefit; over $€ 1$ bn in healthcare cuts; and adjustments to the universal social charge to gain revenue from those over aged 70 (Govt of Ireland 2012). In addition, the budget included some particularly regressive measures such as increase in Pay Related Social Insurance (PRSI) contributions, but in a form that especially hit low-paid workers. More- 
over, the unemployed were targeted via a three-month reduction in the duration of jobseeker's benefit, which is paid to the newly-unemployed. Meanwhile, pension tax relief, which overwhelmingly benefits the wealthy, was left untouched in the budget and higher earners as a whole again avoided income tax increases.

Plainly, the upshot of all these adjustments is that inequality in Ireland has increased. For example, Ireland's Gini coefficient increased from 30.7 in 2008 to 31.1 in 2011 (CSO, 2011): whereas the average income of the highest income quintile was 4.6 times that of the lowest income quintile in 2008, by 2011 the ratio was 4.9. These slight increases in certain measures of inequality need to be seen alongside measures of poverty and deprivation, which illustrate the depth of Ireland's crisis. For example, whereas $13.8 \%$ of the surveyed population experienced two or more types of enforced deprivation in 2008, almost one quarter $(24.5 \%)$ fell into this category by 2011 (CSO, 2011). In addition, while the percentage of people in consistent poverty in 2008 was $4.2 \%$, this had increased to $6.9 \%$ in 2011 . If one aim of neoliberal adjustments is to re-assert class power, in part by increasing inequality, then Ireland's austerity programme has done its job.

\section{Discussion}

How can we make sense of Ireland's case, not least the fact that the austerity programme has not faced significant resistance? As has been noted elsewhere (e.g. see Storey 2011), Ireland's story since 2008 smacks of what Naomi Klein (2007) calls the 'shock doctrine,' via which neoliberal champions exploit crisis periods to push through policies and 'reforms' that claim to be about crisis resolution, but in fact tend to have highly problematic social impacts on workers and other citizens. Using examples from a wide range of places around the world - including Chile, Bolivia, Mexico, numerous places throughout Sub-Saharan Africa, and then Russia (see also Harvey, 2003, 2005; Peet, 2009) - Klein argues that this sort of opportunism often occurs via structural adjustment programmes following on from IMF debt bailouts. Although it has not been labelled as such, we argue that Ireland's austerity programme must be viewed as just such a structural adjustment programme: one with cutbacks, deregulation, and efforts to reconfigure class relations not least by socializing private losses in the financial sector. However, in trying to grasp the Irish case, we argue that the shock doctrine does not quite capture what has occurred. Rather than a series of shocks - rather than inflicting injuries "all at once" (Klein, 2007: 7) - something slightly more subtle and incremental has been happening in Ireland. To help characterize this approach in Ireland, consider something Marx and Engels wrote about capitalism in a famous passage of The Communist Manifesto:

The bourgeoisie cannot exist without constantly revolutionising the instruments of production, and thereby the relations of production, and with them the whole relations of society. Conservation of the old modes of production in unaltered form, was, on the contrary, the first condition of existence for all earlier industrial classes. Constant revolutionising of production, uninterrupted disturbance of all social conditions, everlasting uncertainty and agitation distinguish the bourgeois epoch from all earlier ones. All fixed, fast-frozen relations, with their train of ancient and venerable prejudices and opinions, are swept away, all new-formed ones become antiquated before they can ossify. All that is solid melts into air, all that is holy is profaned, and man is at last compelled to face with sober senses his real conditions of life, and his relations with his kind (Marx and Engels 1967; our emphasis).

We argue the idea of 'uninterrupted disturbance' is an accurate way to characterise the first few years of Ireland's structural adjustment. Of fundamental importance here is that the adjustment in Ireland has been about the gradual but constant shaking of workers' confidence; chipping away at any gains they might have made, frightening and agitating them with apocalyptic warnings about economic collapse and the dire state of the country's finances. Thus, at one stage Irish (and indeed foreign investing) capitalists seek to strike at private sector pay rates and employ- 
ment; and then at another, the state tries to scare its employees (and indeed their labour union leadership) to accept consecutive rounds of pay freezes, pay cuts, and deteriorating working conditions as well as rolling back the welfare state in the name of competitiveness. Elsewhere, 'innovations' such as NAMA, the almost silent and invisible repayment of bondholders, and a host of other minor but important policy adjustments dump more debt onto workers and citizens, or disturb the property market in ways that lock-in privileges and rights that will inevitably benefit only a wealthy minority. The adjustment in Ireland has been characterized by this gradual, experimental process: one that entails examining what works (the first PSA, for example) and trying to go for more (as the attempted second PSA indicates); but also examining what fails (attempted cuts in minimum wages, say) and testing alternatives, such as the Pathways to Work programme. Just as Harvey (2005: 13) notes that capitalist states everywhere more or less stumbled into neoliberalism - just as neoliberalization entails experiments, trials and errors - then the unavoidable conclusion to draw about the adjustment in Ireland is that it entails a sustained but experimental effort at disturbing, shaking, agitating, and unsettling workers and their existing social conditions with the outcome of increased, everlasting uncertainty and agitation.

Why Ireland has seen a process of uninterrupted disturbance rather than the shock doctrine is obviously up for question. We argue two factors are important. One is that, unlike those places targeted during the heydays of structural adjustment in the 1980s and 1990s, Ireland's crisis has not entailed rampant inflation. There simply has not been any need to push for the short sharp shocks that neoliberal policy advisors looked for in Bolivia, say. In addition, currency devaluation, one of the main weapons of the shock doctrine, has not been possible in Ireland given its membership of the Eurozone. Further, although it seems from the Cyprus case that the ECB has adapted its approach to such an extent that shock tactics are now on the table (most notably a 'haircut' on savings over $€ 100,000$ and a raft of capital controls), at the time of the Irish bailout the ECB seemed to be more intent on achieving some degree of crisis resolution without having Ireland splashed across the front pages. Thus, a structural adjustment programme was to take place in Ireland, but without any headlines about capital controls or other radical moves.

The second factor leading to uninterrupted disturbance in the Irish austerity programme is Ireland's position as an export platform, one so heavily dependent on foreign investment (as much as $90 \%$ of export sales from Ireland go to foreign-owned firms (Forfás 2010). Thus, both austerity-era governments and the troika have sought to implement the structural adjustment without a significant upsurge in industrial action. As the first PSA clearly displays, the aim has been to avoid a wave of strikes by securing the sort of 'stability' promised to Ireland's foreign inward investors by the Irish Development Agency, along with its allies in the Irish Business and Employers Confederation and the American Chamber of Commerce. Just such peace has indeed been achieved in Ireland: although they have called some protest marches and demonstrations, Ireland's public sector unions have thus far been remarkably calm. The gradual, quiet and indeed subtle process of shaking the confidence of workers and citizens has been able to achieve the government and troika's aims, whilst minimizing the disruption to the economy's core private sector firms. Indeed, the degree of industrial peace in Ireland has helped the state return to the international bond markets in advance of the bailout period ending. Any confidence investors might have in Ireland is bound up with the continuation of work, with the absence of strike action or any other form of significant militancy. Crucially, moreover, uninterrupted disturbance in a place such as Ireland has had the added advantage of further atomizing society, deepening the already stark divisions that exist between different strata of Ireland's workforce. Had the government pursued the sort of shock therapy that some influential commentators argued was necessary, the great threat was that Irish workers might have discovered more about what they had in common and developed a sense of their potential as a united force against the coalition seeking to dump the bank debts onto their shoulders. Uninterrupted disturbance, not shock therapy, has been the effective approach to extending and deepening the grip of neoliberal ideas and practice in Ireland. 


\section{Conclusion}

In summary, we have outlined structural adjustment measures regarding finance and property, the labour market, and state spending. In each area, we have highlighted particularly striking effects, such as the re-positioning of Ireland relative to wider financial flows; labour market changes designed to discipline Irish workers, ostensibly to improve their competitiveness, whilst also creating new elite labour market segments that aim to draw in new investment; and new efforts to activate and mobilize the unemployed, most notably the government's Pathways programme. We use these sorts of adjustments - examples of the 'topographies and topologies' (Kitchin et al., 2012a) of Ireland's encounter with neoliberal ideas and practices - to argue that efforts to deal with the crisis deepen and extend the hegemony of neoliberal ideas and practice. But while the new policies and programmes use the shock of crisis to disturb and disrupt specific aspects of Irish society and economy, they utterly fail to alter the patterns of decision-making and strategizing that got the country into the mess it is facing. Rather, the trajectory of Ireland's crisis period from 2008-2012 has been dominated by the state's effort to rescue the domestic financial system via an act of class restoration that redistributes the burden of paying bank debts from financial and property elites to ordinary workers and citizens. Further, although there has been considerable domestic pressure on both crisis-period governments to force bondholders to absorb some losses on their investments in Irish institutions, the European Central Bank - with support from US Treasury Secretary Timothy Geithner (Kelly, 2011) - has resolutely opposed such a move. In this sense, Ireland plays a role in sending a message to investors that banking crises will be paid for by general austerity; that is, private debts in the financial sector will become socialized.

The lesson here is a familiar one: financialisation of the economy hinges on states enforcing finance capital's dominance over citizens. Locally, moreover, insofar as the Irish state has made efforts to restore the property market by actively reconfiguring the ownership of assets, it is the members of the same class of financial elites with greatest access to liquid capital that stand to gain the most from such moves. Nothing about Ireland's story suggests there is any prospect of a redistribution of wealth to reduce inequality; rather, Ireland's neoliberal policy regime has firmly steered decision-makers towards policies that deepen inequality, often with perverse effects. In conjunction with these material rearrangements, moreover, there has been an ideological readjustment involving the construction of new rationalities suited to the needs of a more punitive and volatile mode of governance. Enactment of the bank guarantee was crucial in this regard because it provided the straightjacket within which public discussion and policy-making would be constrained. Instead of debating the existing (and alternative) structural responses to the crisis, a supposedly pragmatic, technical exercise in revenue generation and cost-cutting initiatives took centre stage. The government and the troika now have a mandate to introduce more entrenched neoliberal measures.

Clearly, therefore, the response to Ireland's crisis reveals the essential nature of neoliberal ideas and practice: not withdrawal of the state from the economy, but heavy intervention on the side exclusively of finance capital. Thus, Peck et al. (2009: 105-6) were correct to caution about the rush to issue neoliberalism's death warrant emphasising that 'neoliberalism was both conceived and born as a crisis theory [and] has been repeatedly remade through crises'. The problem is that, once neoliberal ideas gain a foothold they prove difficult to displace, as indeed the case of Ireland highlights: a case of more neoliberalism to fix a neoliberal crisis. In many respects, of course, this is what we should expect. Without any significant upsurge in protest or the formation of new political alliances on the left, it is hardly surprising that neoliberal ideas and practice have continued to exert influence in Ireland. As the case of Ireland's Special Assignee Relief Programme illustrates, moreover, there are powerful, well-resourced and articulate champions of neoliberal policy, such as KPMG and their ilk -- exactly the sorts of social forces outside the state that manage to out-manoeuvre and drown out critical voices in civil society; the same forces, moreover, that create a situation in which, as Peet (2011: 32) notes, 'the neoliberal state is imposing sanctions - not on the speculators, 
but on the hardworking people whose taxes bailed out the financial system! Austerity is punishment for the crimes of the wealthy, but is imposed on everyone but the culprits'. In this sense, deepening and extending austerity in Ireland is just another means of achieving the more general neoliberal aim of redistributing economic output to capitalists. It is, then, and indeed overtly, class warfare.

\section{References:}

Allen K (2007) The Corporate Takeover of Ireland. Dublin: Irish Academic Press.

Central Bank of Ireland (2013) Residential Mortgage Arrears and Repossession Statistics: Q4 2012. Available at: http:/www.centralbank.ie/polstats/stats/ mortgagearrears/documents/2012q4_ie_mortgage_ arrears_statistics.pdf

Central Statistics Office (2011) Survey on Income and Living Conditions. Available at: http://www.cso. $\mathrm{ie} / \mathrm{en} / \mathrm{media} / \mathrm{csoie} /$ releasespublications/documents/ silc/2011/silc_2011.pdf

Central Statistics Office (2012) Population and Migration Estimates April 2012. Available at: http:// www.cso.ie/en/media/csoie/releasespublications/ documents/population/2012/popmig_2012.pdf

Department of Social Protection (2012) Pathways to Work: Government Policy Statement on Labour Market Activation. Available at: http://www.welfare. ie/en/Schemes/JobseekerSupports/Documents/PathwaysToWork.pdf

Denning M (2010) Wageless life. New Left Review 66: 79-97.

Department of Finance (2010) EU/IMF Programme of Financial Support for Ireland. Available at: http://www.finance.gov.ie/documents/publications/reports/2011/euimfrevised.pdf
Department of Public Expenditure and Reform (2010) Government of Ireland Public Service Agreement, 2010 - 2014. Available at: http://hr.per.gov.ie/ files/2011/09/Public-Service-Agreement-2010-14.pdf

Drudy PJ and Collins ML (2011) Ireland: from boom to austerity. Cambridge Journal of Regions, Economy and Society 4: 339-354.

European Commission (2011) Statistical Annex of European Economy, Autumn 2011. Available at: http://ec.europa.eu/economy_finance/ publications/european_economy/2011/ pdf/2011-1110-stat-annex_en.pdf

FÁS (2012) Community employment programme. Available at: http://www.fas.ie/en/Communities/ Community+Employment/default.htm

Financial Times (2012) Barclay brothers win hotel dispute. August 10.

Finn D (2011) Ireland on the turn? New Left Review 67: 5-39.

Forfás (2010) Annual Business Survey of Economic Impact 2010. Available at: http://www.forfas.ie/ media/FF08062012-ABSEI-Publication.pdf

Frank T (2000) One Market Under God: Extreme Capitalism, Market Populism, and the End of Economic Democracy. New York: Doubleday.

Government of Ecuador (2008) Internal auditing commission for public debt of Ecuador. Available at: http://www.jubileeusa.org/fileadmin/user_upload/ Ecuador/Internal_Auditing_Commission_for_ Public_Credit_of_Ecuador_Commission.pdf

Government of Ireland (2012) Expenditure Report 2013. Available at: http://budget.gov. ie/Budgets/2013/Documents/Expenditure\%20 Report\%202013\%20Parts\%20I\%20-\%20IV.pdf 
Glassman J (2007) Recovering from Crisis: The Case of Thailand's Spatial Fix. Economic Geography 83: 349-370.

Harvey D (2003) The new imperialism. Oxford: Oxford University Press.

Harvey D (2005) A Brief History of Neoliberalism: Oxford University Press.

Harvey D (2010) The Enigma of Capital and the Crisis this Time. Available online at: http://davidharvey.org/2010/08/ the-enigma-of-capital-and-the-crisis-this-time/

Hung H (2009) America's Headservant? The PRC's Dilemma in the Global Crisis. New Left Review 60: 5-25.

ILO (2012) World of work report 2012: Better jobs for a better economy. Geneva: International Labour Office, International Institute for Labour Studies. Available at: http://www.ilo.org/global/research/ global-reports/world-of-work/WCMS_179453/lang-en/index.htm

IMF (2012) Ireland: Selected Issues. IMF Country Report No. 12/265. Washington DC: IMF. Footnote 10.

IMF (2013) Ireland: Ninth Review Under the Extended Arrangment. IMF Country Report No. 13/93. Washington DC: IMF. Available at: http://www.imf. org/external/pubs/ft/scr/2013/cr1393.pdf

Irish Times (2011a) If NAMA cannot meet its target Ireland has bigger problems. December 9.

Irish Times (2011b) No doubt this was a pro-business, pro-growth budget. December 7 .

Irish Times (2012a) New Burlington Hotel owners seek further properties. November 26. Available at: http:/www.irishtimes.com/newspaper/ finance/2012/1126/1224327093675.html
Irish Times (2012b) Multinationals benefit as their financial advisers pile pressure on governments. April 23. Available at: http://www.irishtimes.com/newspaper/finance/2012/0423/1224315050165.html

Kelly M (2011) Ireland's future depends on breaking free from bailout. Irish Times May 5.

Kitchin R, O'Callaghan C, Boyle M, Gleeson J, and Keaveney K (2012a) Placing neoliberalism: The rise and fall of Ireland's Celtic Tiger. Environment and Planning A 44: 1302 - 1326.

Kitchin R, O'Callaghan C, and Gleeson J (2012b) Unfinished estates in Post-Celtic Tiger Ireland (NIRSA) Working Paper Series No. 67. NIRSA - National Institute for Regional and Spatial Analysis.

Klein N (2007) The shock doctrine: The rise of disaster capitalism. Toronto: Alfred A. Knopf Canada.

Labour Relations Commission (2013) Draft public service agreement. Available at: http://per.gov.ie/ wp-content/uploads/LRC-Proposals-printed.pdf

MacLeavy J and Peoples CL (2009) WorkfareWarfare: Neoliberalism, 'Active' Welfare and the New American Way of War. Antipode 41: 890-915.

Mansell W and Openshaw K (2009) Suturing the Open Veins of Ecuador: Debt, Default and Democracy. The Law and Development Review 2:1, Article 7, 150-191.

Marx, K. \& Engels, F. (1967) The Communist Manifesto. London: Penguin.

Münchau W (2010) Why the EU's bank rescue strategy is turning into a political and economic catastrophe. Available at: http://www.eurointelligence.com/ eurointelligencenews/archive/single-view/article/ why-the-eus-bank-rescue-strategy-is-turning-into-apolitical-and-economic-catastrophe.html 
NAMA (2012) National Assets Management Agency Annual Report and Financial Statements 2011. Available at: http://www.nama.ie/download/publications/NAMAAnnualReport2011.pdf

O’Toole F (2009) Ship of Fools: How Stupidity and Corruption Sank the Celtic Tiger. London: Faber.

Peck J (2001) Workfare states. New York: Guilford.

Peck J \& Tickell A (2002) Neoliberalizing space. Antipode. 34: 380-404.

Peck J, Theodore N, and Brenner N (2009) Postneoliberalism and its malcontents. Antipode 41: 94-116.

Peet R (2009) Unholy Trinity: The IMF, World Bank and WTO. London: Zed Press,
Peet R (2011) Contradictions of finance capitalism. Monthly Review December: 18-32.

Ross S (2009) The bankers: how the banks brought Ireland to its knees. Dublin: Penguin Ireland.

Storey A (2011) Ireland's Debt Crisis: Roots and Reactions. Irish New Left Review. Available at: http://www.irishleftreview.org/2011/11/21/ irelands-debt-crisis-roots-reactions/

Tasc (2010) Response to Budget 2011. Available at: http://www.tascnet.ie/upload/file/TASC $\% 20$ Response\%20to\%20Budget\%202011.pdf

Tasc (2011) Response to Budget 2012. Available at: http://www.tascnet.ie/upload/file/Roadmap\%20 to\%20Greater\%20Inequality_final.pdf

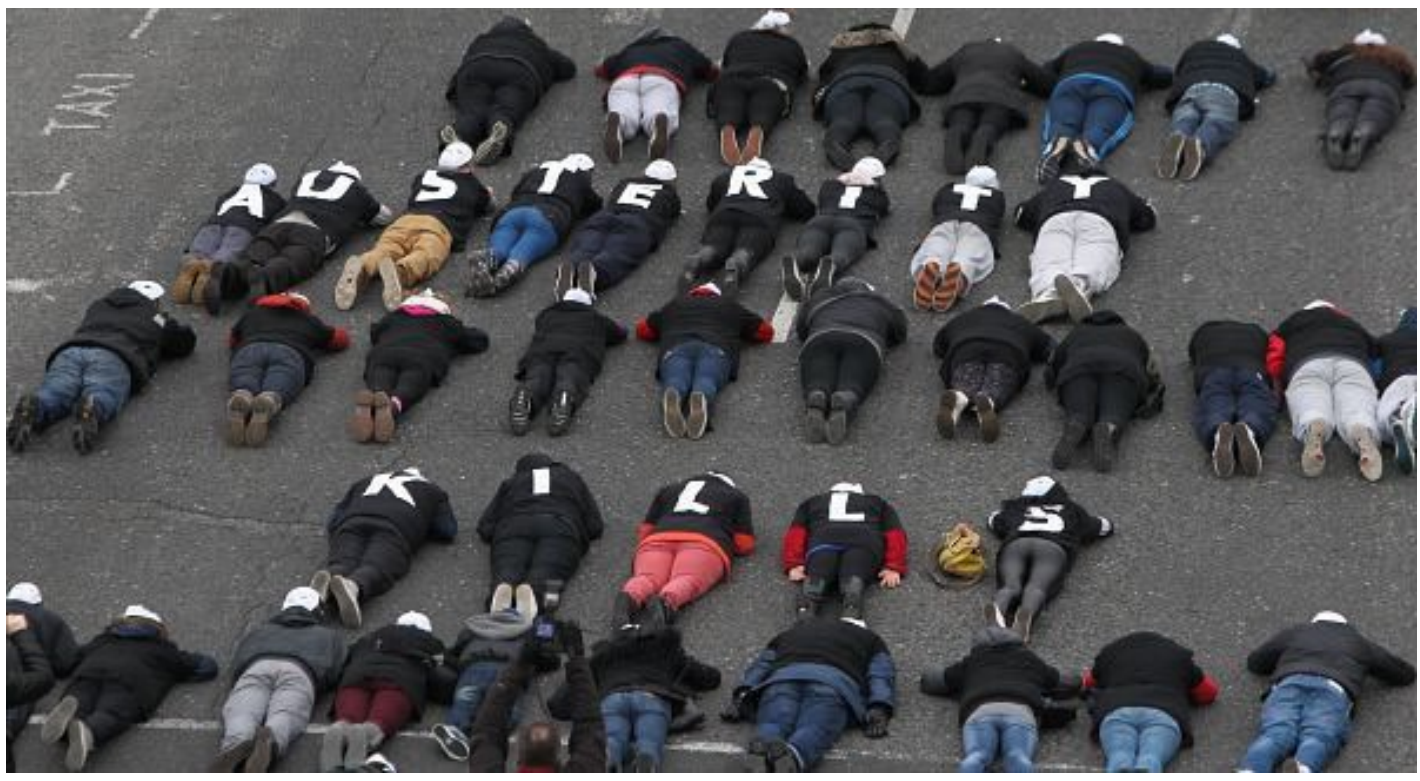

